\title{
CLINICAL USES OF 2,3-DIMERCAPTOPROPANOL (BAL). X. THE TREATMENT OF ACUTE SYSTEMIC MERCURY POISONING IN EXPERIMENTAL ANIMALS WITH BAL, THIOSOR- BITOL AND BAL GLUCOSIDE
}

\author{
By ALFRED GILMAN,1 ROBERTA P. ALLEN, FREDERICK S. PHILIPS, 2 \\ AND ELLEN ST. JOHN ${ }^{3}$ \\ (From the Pharmacology Section, Medical Division, Chemical Warfare Service, \\ Edgewood Arsenal, Maryland)
}

(Received for publication February 5, 1946)

\begin{abstract}
Although chemical agents were not employed as offensive weapons during the past war, nevertheless it was imperative to pursue vigorously investigations on the treatment of chemical warfare casualties. Inasmuch as a number of chemical warfare agents contain arsenic, attention was focused on the synthesis of compounds capable of antagonizing the local and systemic effects of arsenical vesicants. These investigations, initiated by the British, led to the synthesis of 2,3-dimercaptopropanol, which is now more familiarly known as BAL (British Anti-Lewisite). In addition to $\mathrm{BAL}$, numerous other $\mathrm{SH}$-containing compounds, including monothiols and dithiols of polyhydric alcohols, were synthesized by the American and British investigators. Among these were thiosorbitol, prepared at the du Pont de Nemours and Company laboratories, and the glucoside of BAL, first synthesized by Danielli and co-workers (1).
\end{abstract}

The historical background which led to the synthesis of BAL and its derivatives, and the basic contributions which have resulted from studies on the effect of mercaptans on the toxic action of arsenic and other heavy metals, have been summarized by Peters (2) and Waters and Stock (3). Pertinent to the background of the present study were the observations supporting the general hypothesis that heavy metals are toxic to biological systems because of their reaction with $\mathrm{SH}$ groups of the protein moiety of cellular enzymes to form mercaptides. That mercury shares in this action has been demonstrated by Barron and co-workers (3). Moreover, BAL is capable of reactivating enzyme systems poisoned by mercury,

\footnotetext{
1 Major, Sn-C., A.U.S.

2 1st Lt., Sn-C., A.U.S.

3 2nd Lt., Sn-C., W.A.C.
}

a fact which both affords support to the theory of the mechanism of inactivation, and gives promise for the therapeutic efficacy of mercaptans in the treatment of mercury poisoning. The present report is concerned with the efficacy of BAL, BAL glucoside and thiosorbitol in the treatment of experimental, acute, systemic mercury poisoning in rabbits and dogs.

\section{The reactions between mercaptans and $\mathrm{Hg}^{++}$in vitro}

The reactions between mercaptans and cationic mercury which occur in vitro are presumably indicative of the expected interaction of the two agents in vivo. A brief study of the chemical reactions between the various mercaptans and mercury was, therefore, undertaken.

Reactions with $B A L$. When solutions of $\mathrm{HgCl}_{2}(0.1$ $\mathrm{M})$ were added to non-buffered, aqueous solutions of BAL $(0.05 \mathrm{M})$ a copious, flocculent white precipitate formed. Titration with phenolphthalein as an indicator revealed the formation of 2 equivalents of $\mathrm{H}^{+}$for each mol of $\mathrm{HgCl}_{2}$ added. The white precipitate was insoluble in alkali, but could be dissolved upon the addition of concentrated $\mathrm{HCl}$. On the basis of analogy to the reactions of BAL with arsenicals $(2,3)$ the complex (hereafter called $\mathrm{Hg}-\mathrm{BAL}$ ) presumably possessed the following structure:

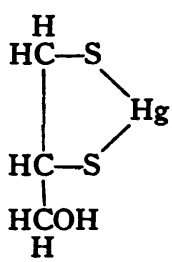

The complex was sufficiently dissociable so that the addition of neutral solutions of $\mathrm{Na}_{2} \mathrm{~S}$ to a suspension of the mercaptide resulted in the formation of a copious, black precipitate of $\mathrm{HgS}$.

Of greater importance than the formation of the insoluble $\mathrm{Hg}-\mathrm{BAL}$ complex, was the reaction which took 
place when $\mathrm{Hg}^{++}$was introduced into alkaline solutions of BAL maintained at $\mathrm{pH}$ 7.5. Under these conditions the addition of $\mathrm{Hg}^{++}$in the molar proportion of $1 \mathrm{Hg}: 2$ BAL resulted in the formation of a complex which was soluble and so little dissociated that the addition of neutral solutions of $\mathrm{Na}_{2} \mathrm{~S}$ did not precipitate $\mathrm{HgS}$. A simple formulation for the di-sodium salt of this complex (hereafter designated as $\left.\mathrm{Hg}(\mathrm{BAL})_{2}\right)$ is as follows:<smiles>OC(O)C=[SH]CC(O)C(O)O</smiles>

Evidence was also obtained that soluble complexes containing mercury and BAL in the molecular ratios of $2: 3$ could also be formed at slightly alkaline $\mathrm{pH}$.

Reactions with 1-thiosorbitol. The reaction of $1 \mathrm{~mol}$ of $\mathrm{HgCl}_{2}(0.1 \mathrm{M})$ and 2 mols of 1-thiosorbitol $(0.05 \mathrm{M})$ in aqueous solution resulted in the liberation of $2 \mathrm{mols}$ of $\mathrm{H}^{+}$as determined by titration and the formation of a complex which presumably has the following structural formula :<smiles>OC(O)C(O)CSSCC(O)C(O)O</smiles>

The complex, hereafter designated as $\mathrm{Hg}$ (thiosorbitol), dissociates to the extent that the addition of neutral solutions of $\mathrm{Na}_{2} \mathrm{~S}$ results in the copious precipitation of $\mathrm{HgS}$.

Reactions with $B A L$ glucoside. BAL glucoside was obtained as the barium salt. The compound contained approximately theoretical amounts of barium and sulfur, but only 60 to 70 per cent of theoretical SH activity. The sodium salt of the glucoside was formed by the addition, to solutions of the barium salt, of a slight excess of $\mathrm{Na}_{2} \mathrm{SO}_{4}$ and the $\mathrm{pH}$ adjusted to $c a .7 .4$ by the addition of $\mathrm{HCl}$. The $\mathrm{BaSO}_{4}$ was removed by centrifugation, and aliquots of the filtrate were titrated iodometrically for $\mathrm{SH}$ activity. The molar equivalence of the reactions below was calculated in terms of dithiol activity as determined analytically. When solutions of $0.1 \mathrm{M} \mathrm{HgCl}_{2}$ were reacted with those of $0.05 \mathrm{M}$ BAL glucoside in the molar proportion of $1: 1$, the addition of neutral solutions of $\mathrm{Na}_{2} \mathrm{~S}$ resulted in the precipitation of $\mathrm{HgS}$. Presumably a soluble mercaptide ( $\mathrm{Hg}$-BAL glucoside) with appreciable dissociation was formed. The further addition of a second mol of BAL glucoside in an alkaline medium $(\mathrm{pH} 7.5$ or greater) resulted in the formation of a complex $(\mathrm{Hg}$ (BAL glucoside) ${ }_{2}$ ) unaffected by $\mathrm{Na}_{2} \mathrm{~S}$ which may be considered to have the following structure:

\footnotetext{
4 Received from Dr. B. W. Howk and Dr. W. H. Vinton of the du Pont Laboratories, Wilmington, Del.
}

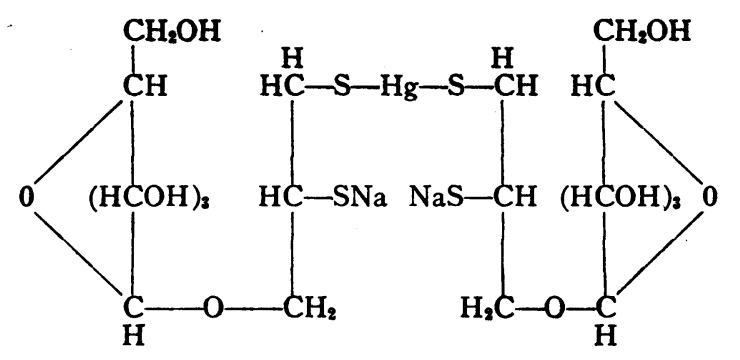

Treatment of systemic mercury poisoning in
rabbits

For the determination of the efficacy of mercaptans in the treatment of acute systemic mercury poisoning in rabbits, solutions of $\mathrm{HgCl}_{2}$ were administered intravenously. The lethality of 0.3 per cent solutions of $\mathrm{HgCl}_{2}$ to adult rabbits of mixed sex is shown in Table $I$. A standard dose

TABLE I

The toxicity of $\mathrm{HgCl}_{2}$ administered intravenously in rabbits

\begin{tabular}{r|r|r|r|r|r|r}
\hline \hline $\begin{array}{c}\text { Dose } \\
\text { HgCl }\end{array}$ & Mortality & \multicolumn{5}{|c}{ Day of death } \\
\cline { 2 - 6 } & & 0 to 2 & 2 to 4 & 4 to 6 & 6 to 8 & 8 to 14 \\
\hline $\begin{array}{c}m g m . \\
\text { per } \mathrm{kgm} .\end{array}$ & & & & & & \\
2.0 & 6 out of 10 & & 1 & 2 & 2 & 1 \\
3.0 & 78 out of 81 & 6 & 39 & 22 & 6 & 5 \\
5.0 & 2 out of 2 & & 1 & & 1 & \\
10.0 & 1 out of 1 & 1 & & & & \\
25.0 & 2 out of 2 & 2 & & & & \\
\hline
\end{tabular}

of $3.0 \mathrm{mgm}$. per $\mathrm{kgm}$. $\left(\mathrm{LD}_{98}\right)$ was employed as a background for the therapeutic study. The majority of rabbits receiving this dose died between the second and sixth days. Deaths, other than those which occurred acutely; were invariably associated with renal insufficiency as evidenced by the marked and progresive elevation of serum NPN or urea N. The determination of either NPN (micro-Kjeldahl) or urea N (Van Slyke and Cullen) was routinely performed 2, 4 and 14 days after the administration of mercury. Even after the injection of $2.0 \mathrm{mgm}$. per $\mathrm{kgm}$. of $\mathrm{HgCl}_{2}$, 100 per cent of animals showed marked elevations in NPN, although a small percentage survived.

The effect of treatment with BAL, 1-thiosorbitol or BAL glucoside on the course of acute mercury intoxication in rabbits is presented in Table II. If treatment was initiated within 5 minutes, 3 mercaptans were completely effective in preventing death when given in the total dose of $0.3 \mathrm{mM}$. per 
TREATMENT OF MERCURY POISONING WITH BAL AND THIOSORBITOL

TABLE II

The effect of mercaptan therapy in rabbits following the intravenous administration of an $L D_{96}$ of $\mathrm{HgCl}_{2}$

\begin{tabular}{|c|c|c|c|c|c|c|c|c|}
\hline \multirow{2}{*}{$\begin{array}{l}\text { Interval } \\
\text { before } \\
\text { initiation } \\
\text { of therapy }\end{array}$} & \multicolumn{3}{|c|}{ Dose of Thiol* } & \multirow{2}{*}{ Mortality } & \multirow{2}{*}{$\begin{array}{c}\text { Incidence of renal } \\
\text { insufficiency in } \\
\text { animals surviving } \\
48 \text { hrs. }\end{array}$} & \multicolumn{3}{|c|}{ Time of death in days } \\
\hline & BAL & 1-Thiosorbitol & BAL glucoside & & & 0 to 4 & 4 to 8 & 8 to 30 \\
\hline \multirow[t]{3}{*}{$\min }$. & $\begin{array}{c}m M . \text { per } \mathrm{kgm} . \\
3 \times 0.1 \\
3 \times 0.05 \\
3 \times 0.008 \\
1 \times 0.011\end{array}$ & $m M$. per $k g m$. & $m M$. per kgm. & $\begin{array}{l}0 \text { out of } 10 \\
0 \text { out of } 9 \\
3 \text { out of } 10 \\
8 \text { out of } 10\end{array}$ & $\begin{array}{c}1 \text { out of } 10 \\
0 \text { out of } 9 \\
10 \text { out of } 10 \\
9 \text { out of } 9\end{array}$ & $\begin{array}{l}1 \\
1\end{array}$ & 2 & $\begin{array}{l}2 \\
5\end{array}$ \\
\hline & & $\begin{array}{l}3 \times 0.1 \\
3 \times 0.05\end{array}$ & & $\begin{array}{l}0 \text { out of } 10 \\
4 \text { out of } 10\end{array}$ & $\begin{array}{r}2 \text { out of } 10 \\
10 \text { out of } 10\end{array}$ & 2 & 1 & 1 \\
\hline & & & $\begin{array}{l}3 \times 0.1 \\
3 \times 0.05 \\
3 \times 0.011\end{array}$ & $\begin{array}{l}0 \text { out of } 10 \\
1 \text { out of } 10 \\
2 \text { out of } 10\end{array}$ & $\begin{array}{l}0 \text { out of } 10 \\
0 \text { out of } 10 \\
3 \text { out of } 9\end{array}$ & $\begin{array}{l}1 \\
1\end{array}$ & & 1 \\
\hline \multirow[t]{3}{*}{30} & $\begin{array}{l}5 \times 0.1 \\
3 \times 0.1 \\
3 \times 0.05\end{array}$ & . & & $\begin{array}{l}6 \text { out of } 10 \\
2 \text { out of } 10 \\
5 \text { out of } 10\end{array}$ & $\begin{array}{l}8 \text { out of } 10 \\
10 \text { out of } 10 \\
10 \text { out of } 10\end{array}$ & $\begin{array}{l}2 \\
1 \\
2\end{array}$ & $\begin{array}{l}3 \\
1 \\
1\end{array}$ & $\begin{array}{l}1 \\
2\end{array}$ \\
\hline & & $\begin{array}{l}3 \times 0.8 \\
3 \times 0.4 \\
3 \times 0.1\end{array}$ & & $\begin{array}{l}9 \text { out of } 10 \\
2 \text { out of } 8 \\
6 \text { out of } 10\end{array}$ & $\begin{array}{l}6 \text { out of } 6 \\
7 \text { out of } 7 \\
9 \text { out of } 10\end{array}$ & $\begin{array}{l}6 \\
1\end{array}$ & $\begin{array}{l}1 \\
5\end{array}$ & $\begin{array}{l}2 \\
1 \\
1\end{array}$ \\
\hline & & . & $\begin{array}{l}3 \times 0.1 \\
3 \times 0.05\end{array}$ & $\begin{array}{l}4 \text { out of } 10 \\
4 \text { out of } 9\end{array}$ & $\begin{array}{l}7 \text { out of } 9 \\
6 \text { out of } 9\end{array}$ & 1 & $\begin{array}{l}2 \\
2\end{array}$ & $\begin{array}{l}1 \\
2\end{array}$ \\
\hline \multirow[t]{3}{*}{60} & $\begin{array}{l}3 \times 0.1 \\
3 \times 0.05\end{array}$ & & & $\begin{array}{r}10 \text { out of } 10 \\
8 \text { out of } 10\end{array}$ & $\begin{array}{l}10 \text { out of } 10 \\
10 \text { out of } 10\end{array}$ & $\frac{1}{3}$ & $\begin{array}{l}5 \\
2\end{array}$ & $\begin{array}{l}4 \\
3\end{array}$ \\
\hline & & $3 \times 0.4$ & & 8 out of 10 & 9 out of 9 & 2 & 5 & 1 \\
\hline & & & $3 \times 0.1$ & 8 out of 10 & 10 out of 10 & 1 & 1 & 6 \\
\hline
\end{tabular}

* BAL and 1-Thiosorbitol given in 3 equally divided doses, the first, intravenously, and the second and third, intramuscularly, respectively 1 and 3 hours later. Any subsequent doses were given at 2-hour intervals. BAL glucoside given similarly, except that all injections were intravenous. BAL administered in propylene glycol (0.5 mM. per ml.). 1-Thiosorbitol and BAL glucoside administered in aqueous solution.

kgm. Of even greater significance was the fact that a rise in NPN was observed in only 3 of the 30 animals. When the dose was reduced to a total of $0.15 \mathrm{mM}$. per $\mathrm{kgm}$., the superiority of the dithiols, BAL and BAL glucoside, over the monothiol, 1-thiosorbitol, became apparent. It is also of interest to observe that BAL in the total dose of only $0.025 \mathrm{mM}$. per $\mathrm{kgm}$. reduced mortality to 30 per cent, although the incidence of renal insufficiency was 100 per cent.

The fact that BAL does not represent the ultimate goal in the therapy of mercury poisoning with dithiols, is shown by the superiority of BAL glucoside when compared with BAL at the dose level of $0.011 \mathrm{mM}$. per $\mathrm{kgm}$. This dose was chosen because it is the molar equivalent of the dose of $\mathrm{HgCl}_{2}$ employed. Thus, 5 minutes after the intravenous injection of $\mathrm{HgCl}_{2}$, the administration of a molar equivalent of $\mathrm{BAL}$ glucoside resulted in so effective a combination of BAL glucoside with mercury as to reduce mortality to 20 per cent, and prevent renal damage in the majority of surviving animals.

The adverse effect of a delay in treatment can be seen from the data in Table II. In the rabbit, a therapeutic delay of 30 minutes resulted in an incidence of renal insufficiency of close to 100 per cent. However, all 3 mercaptans were still capable of preventing the death of a high proportion of animals. The data at 30 minutes suggest that increasing the total dose of BAL by extending the period of treatment afforded no greater protection. If treatment was delayed for 60 minutes only an occasional animal survived.

\section{The toxicity of the preformed complexes}

Information on the basic mechanism involved in the treatment of mercury poisoning by mer- 
TABLE III

A comparison of the toxicities of $\mathrm{Hg}(B A L)_{2}, \mathrm{Hg}(1 \text {-thiosorbitol })_{2}$, and $\mathrm{Hg}(B A L \text { glucoside })_{2}$ administered intravenously in rabbits

\begin{tabular}{|c|c|c|c|c|c|c|c|c|c|}
\hline \multicolumn{4}{|c|}{ Dose of preformed complex } & \multirow{2}{*}{ Mortality } & \multirow{2}{*}{$\begin{array}{l}\text { Incidence of } \\
\text { renal insuf- } \\
\text { ficiency* }\end{array}$} & \multicolumn{4}{|c|}{ Day of death } \\
\hline $\mathrm{Hg}(\mathrm{BAL})_{2}$ & $\underset{\text { sorbitol })_{2}}{\mathrm{Hg}(1-\text { thio- }}$ & $\underset{\text { gluçoside }}{\mathrm{Hg} \text {-BAL }}$ & $\underset{\text { glucoside), }}{\mathrm{Hg}(\mathrm{BAL}}$ & & & 0 to 2 & 2 to 4 & 4 to 6 & $>6$ \\
\hline \multirow[t]{4}{*}{$\begin{array}{c}\underset{\text { per }}{\operatorname{mggm}} \mathrm{KgCl}_{2} \\
3.0\end{array}$} & $\underset{\text { per }}{\operatorname{mggm} .} \mathrm{HgCl}_{2}$ & $\underset{\text { per }}{\operatorname{mggm} .} \mathrm{kgCl}_{2}^{\mathrm{Hg}}$ & $\underset{\text { per }}{\operatorname{mggm}} \mathrm{Kg}^{\mathrm{HgCl}}$ & 6 out of 6 & 6 out of 6 & & 3 & & 3 \\
\hline & 3.0 & & & 6 out of 6 & 5 out of 5 & 1 & 5 & & \\
\hline & & $\begin{array}{r}3.0 \\
10.0 \\
25.0\end{array}$ & & $\begin{array}{l}1 \text { out of } 6 \\
4 \text { out of } 4 \\
3 \text { out of } 3\end{array}$ & $\begin{array}{l}4 \text { out of } 6 \\
3 \text { out of } 3 \\
3 \text { out of } 3\end{array}$ & 1 & 2 & $\begin{array}{l}2 \\
1\end{array}$ & $\begin{array}{l}1 \\
1\end{array}$ \\
\hline & & & $\begin{array}{r}3.0 \\
10.0 \\
25.0\end{array}$ & $\begin{array}{l}0 \text { out of } 6 \\
0 \text { out of } 4 \\
3 \text { out of } 4\end{array}$ & $\begin{array}{l}1 \text { out of } 6 \\
4 \text { out of } 4 \\
3 \text { out of } 3\end{array}$ & & 1 & & 2 \\
\hline
\end{tabular}

* In animals surviving 48 or 72 hours.

captans was obtained from observations on the toxicity of the preformed complexes of BAL, 1thiosorbitol and BAL glucoside with mercury. The data presented in Table III show that in terms of molar equivalent amounts, the toxicity of $\mathrm{Hg}(\mathrm{BAL})_{2}$ was as great as that of $\mathrm{HgCl}_{2}$. The same was true of $\mathrm{Hg}$ (thiosorbitol) ${ }_{2}$. However, $\mathrm{Hg}-\mathrm{BAL}$ glucoside was significantly less toxic than, and $\mathrm{Hg}$ (BAL glucoside) $)_{2}$ was approximately only $1 / 8$ as toxic as, a molar equivalent amount of $\mathrm{HgCl}_{2}$. The paradoxical fact that a mercaptan effective in the treatment of mercury poisoning forms a complex in vitro which, when administered intravenously, retains the full toxicity of $\mathrm{Hg}^{++}$, will be discussed below.

Treatment of systemic mercury poisoning in dogs.

The efficacy of BAL and BAL glucoside in the treatment of systemic mercury poisoning in dogs was determined following both oral and intravenous administration of $\mathrm{HgCl}_{2}$.

Treatment of intravenous mercury poisoning. Control studies on the intravenous toxicity of $\mathrm{HgCl}_{2}$ in dogs revealed that a dose of $4.0 \mathrm{mgm}$. per $\mathrm{kgm}$. (0.4 per cent solution) was invariably fatal. The majority of dogs died by the 4th day. All of the animals which survived 48 hours showed a marked elevation in serum urea $\mathrm{N}$, the average level at this time being approximately $150 \mathrm{mgm}$. per cent. In those dogs which survived 96 hours, the serum urea $\mathrm{N}$ ranged between 200 and 300 mgm. per cent. One animal died within 24 hours with evidence of massive pulmonary edema. The fact that mercury administered intravenously can damage the pulmonary capillary bed has also been observed by Rosenthal (4). The evaluation of $\mathrm{BAL}$ in the treatment of acute intravenous mercury poisoning in the dog is complicated by the fact that approximately 50 per cent of animals, treated within the first hour, die acutely during the first day of massive pulmonary edema (Table IV). It is known that BAL itself is capable of producing pulmonary edema as a result of a direct toxic action on the capillaries (5). Although the dose of BAL necessary to produce acute deaths from its action on the pulmonary circulation is greatly in excess of that employed in the present study, nevertheless, the possibility of a synergistic action of BAL and mercury on the pulmonary capillary bed must be considered.

Table IV depicts the efficacy of BAL and BAL glucoside when given at varying intervals of time after intravenous $\mathrm{HgCl}_{2}$. When treatment with BAL was delayed for 30 minutes, 6 of 13 animals died acutely of massive pulmonary edema. The surviving animals enjoyed an uneventful recovery and none showed any significant elevation in serum urea N. A delay of 1 hour before the initiation of BAL therapy again resulted in the acute death of 6 of 13 animals. Of the 7 survivors, 4 ultimately succumbed, but death was significantly delayed. Three of these animals exhibited a marked rise in serum urea $\mathrm{N}$, and their deaths must be attributed to renal insufficiency induced by mer- 
cury. One animal survived 11 days, and at no time gave evidence of renal impairment. The 3 survivors showed no effects from the administration of mercury. Of 4 dogs treated with BAL glucoside 1 hour after the administration of mercury, none succumbed and only 1 showed a transient rise in serum urea $\mathrm{N}$ to a level of $70 \mathrm{mgm}$. per cent.

When treatment was delayed for 2 hours, BAL still afforded significant protection. One of 5 animals succumbed to acute pulmonary edema. Of the 4 others, only 1 died with the typical symptoms of mercury poisoning; 1 other animal showed a transient rise in serum urea $\mathrm{N}$ to $40 \mathrm{mgm}$. per cent. BAL glucoside was also highly effective after a therapeutic delay of 2 hours. Only 1 of 6 animals succumbed. Death occurred on the eighth day, with a characteristic rise in serum urea $\mathrm{N}$ concentration. Of the 5 animals which survived, none showed an elevation of urea $\mathrm{N}$ to levels higher than $33 \mathrm{mgm}$. per cent.

In a group of 8 dogs, treatment with BAL glucoside was delayed for 3 hours. Although 6 of the 8 animals succumbed, in 4 death was significantly delayed, occuring 8,12, 12 and 29 days after mercury, respectively. In 2 of these animals the serum urea $N$ rose only to 111 and $136 \mathrm{mgm}$. per cent, and was declining at the time of death. They showed progressive inanition and might have been saved with adequate supportive care.
Of the 2 surviving animals, 1 was completely protected by therapy with BAL glucoside, and the other showed transient elevation of serum urea $\mathrm{N}$ to a level of $42 \mathrm{mgm}$. per cent.

Treatment of oral mercury poisoning. A dose of $30 \mathrm{mgm}$. per $\mathrm{kgm}$. of $\mathrm{HgCl}_{2}$, given as a 1 per cent solution $\left(\mathrm{LD}_{100}\right)$, was employed to test the efficacy of BAL and BAL glucoside in the treatment of oral mercury poisoning. The dogs were starved for 24 hours and given $5 \mathrm{mgm}$. per $\mathrm{kgm}$. of morphine sulfate, intramuscularly, 45 to 60 minutes before the administration of $\mathrm{HgCl}_{2}$ to prevent vomiting. The solution of $\mathrm{HgCl}_{2}$ was introduced by stomach tube. No animal which vomited was considered in the data. It should be emphasized that no lavage or local antidotal therapy was attempted, the animals being completely dependent upon the parenteral administration of the mercaptan to overcome the local effects of mercury within the gastrointestinal tract. In some experiments, both the control and experimental animals received supportive therapy 24 hours after the administration of mercury in the form of an intravenous infusion of $50 \mathrm{ml}$. per $\mathrm{kgm}$. of 0.9 per cent $\mathrm{NaCl}$ and 5.5 per cent glucose, in order to alleviate the dehydration resulting from the severe bloody diarrhea which invariably developed. However, this inadequate procedure failed significantly to influence the course of the animals, and was not routinely employed.

TABLE IV

The effect of $B A L$ and $B A L$ glucoside therapy in dogs receiving $4.0 \mathrm{mgm}$. per kgm. of $\mathrm{HgCl}$ intravenously ( $>L D_{100}$ )

\begin{tabular}{|c|c|c|c|c|c|c|c|c|}
\hline \multicolumn{2}{|c|}{$\begin{array}{l}\text { Time of initiation } \\
\text { of therapy* }\end{array}$} & \multirow{2}{*}{$\begin{array}{c}\text { Number of } \\
\text { animals }\end{array}$} & \multirow{2}{*}{$\begin{array}{l}\text { Acute } \\
\text { pulmonary } \\
\text { deaths }\end{array}$} & \multirow{2}{*}{ Subsequent mortality } & \multirow{2}{*}{$\begin{array}{l}\text { Incidence of renal in- } \\
\text { sufficiency in animals } \\
\text { surviving } 48 \mathrm{hrs.**}\end{array}$} & \multicolumn{3}{|c|}{ Time of death in days } \\
\hline BAL & $\begin{array}{c}\text { BAL } \\
\text { glucoside }\end{array}$ & & & & & 1 to 4 & 4 to 7 & 7 to 30 \\
\hline hrs. & hrs. & 23 & 1 & 22 out of 22 & 17 out of 17 & 15 & 6 & 1 \\
\hline $\begin{array}{l}\frac{1}{2} \\
1 \\
2\end{array}$ & & $\begin{array}{r}13 \\
13 \\
5\end{array}$ & $\begin{array}{l}6 \\
6 \\
1\end{array}$ & $\begin{array}{l}0 \text { out of } 7 \\
4 \text { out of } 7 \\
1 \text { out of } 4\end{array}$ & $\begin{array}{l}0 \text { out of } 7 \\
3 \text { out of } 7 \\
2 \text { out of } 4\end{array}$ & & $\begin{array}{l}3 \\
1\end{array}$ & 1 \\
\hline & $\begin{array}{l}1 \\
2 \\
3\end{array}$ & $\begin{array}{l}4 \\
6 \\
8\end{array}$ & $\begin{array}{l}\mathbf{0} \\
0 \\
0\end{array}$ & $\begin{array}{l}0 \text { out of } 4 \\
1 \text { out of } 6 \\
6 \text { out of } 8\end{array}$ & $\begin{array}{l}1 \text { out of } 4 \\
1 \text { out of } 6 \\
7 \text { out of } 8\end{array}$ & 1 & 1 & $\begin{array}{l}1 \\
4\end{array}$ \\
\hline
\end{tabular}

* $0.15 \mathrm{mM}$. per kgm. of dithiol in 3 equally divided doses. First BAL dose given intravenously, 2nd and 3rd doses, intramuscularly, 2 and 4 hours later, respectively. (Four of the dogs treated with BAL 1 hour after mercury received the first dose intramuscularly.) BAL glucoside given similarly, except that all injections were intravenous. BAL in propylene glycol $(0.5 \mathrm{mM}$. per ml.) used intravenously; BAL in peanut oil (10 per cent solution) used intramuscularly. BAL glucoside administered in aqueous solution.

** Serum urea $\mathrm{N}$ levels greater than $35 \mathrm{mgm}$. per cent. 
The effects of therapy with BAL and BAL glucoside on oral mercury poisoning are summarized in Table V. Of 19 control animals, none survived,

TABLE V

The effect of $B A L$ and $B A \cdot L$ glucoside therapy in dogs receiving $30.0 \mathrm{mgm}$. per $\mathrm{kgm}$. of $\mathrm{HgCl}_{2}$ orally $\left(>L D_{100}\right)$

\begin{tabular}{|c|c|c|c|c|c|c|c|}
\hline \multicolumn{2}{|c|}{$\begin{array}{l}\text { Time of initia- } \\
\text { tion of therapy* }\end{array}$} & \multirow{2}{*}{ Mortality } & \multirow{2}{*}{$\begin{array}{l}\text { Incidence of } \\
\text { renal insuf- } \\
\text { ficiency in } \\
\text { animals sur- } \\
\text { viving 48 } \\
\text { hrs.** }\end{array}$} & \multicolumn{4}{|c|}{ Time of death in days } \\
\hline BAL & $\begin{array}{c}\text { BAL } \\
\text { Gluco- } \\
\text { side }\end{array}$ & & & 0 to 2 & 2 to 4 & 4 to 7 & $>7$ \\
\hline hrs. & hrs. & 19 out of 19 & 15 out of 15 & 4 & 8 & 4 & 3 \\
\hline \multirow[t]{2}{*}{$\begin{array}{l}2 \\
3 \\
5\end{array}$} & & $\begin{array}{l}4 \text { out of } 10 \\
7 \text { out of } 15 \\
2 \text { out of } 5\end{array}$ & $\begin{array}{l}1 \text { out of } 10 \\
2 \text { out of } 9 \\
2 \text { out of } 5\end{array}$ & 2 & $\begin{array}{l}2 \\
2\end{array}$ & $\begin{array}{l}3 \\
2\end{array}$ & 1 \\
\hline & $\begin{array}{l}2 \\
5\end{array}$ & $\begin{array}{l}1 \text { out of } 8 \\
2 \text { out of } 6\end{array}$ & $\begin{array}{l}0 \text { out of } 8 \\
0 \text { out of } 4\end{array}$ & 2 & & 1 & \\
\hline
\end{tabular}

* $0.15 \mathrm{mM}$. per $\mathrm{kgm}$. of dithiol in 3 equally divided doses. Dogs receiving treatment 2 or 3 hours after mercury given dithiol at 2 -hour intervals. Dogs receiving treatment 5 hours after mercury given 2 nd and 3rd doses 2 and 17 hours later, respectively. All BAL injections were intramuscular (10 per cent solution in peanut oil). BAL glucoside administered intravenously in aqueous solution. ** Serum urea $\mathrm{N}$ values greater than $35 \mathrm{mgm}$. per cent.

and all those alive at 48 hours showed elevated serum urea $\mathrm{N}$ values, the average being $100 \mathrm{mgm}$. per cent. This increased progressively to the time of death. Only 3 animals lived for 7 or more days.

When dogs which had received oral mercury were treated 2 hours later with BAL, a high degree of protection was afforded (Table V). Six of 10 animals survived. What is more, as can be seen from Table VI, only 1 of the 10 animals showed evidence of renal insufficiency as judged by a significant rise in the level of serum urea $\mathrm{N}$. In those dogs which died, death could be attributed to a severe hemorrhagic gastro-enteritis. Even more striking results were obtained when treatment with BAL glucoside was instituted 2 hours after the administration of $\mathrm{HgCl}_{2}$. Of 8 treated animals, only 1 succumbed, and in this dog there was no evidence of a significant degree of renal impairment at 48 hours (Table VI).

When BAL was administered 3 hours after $\mathrm{HgCl}_{2}, 7$ of 15 treated animals succumbed. Again only 2 dogs showed elevated serum urea $N$ levels at 48 hours; 1 animal had a level of only $44 \mathrm{mgm}$. per cent and died 6 hours later. This animal was dehydrated from a bloody diarrhea. The second
TABLE VI

The effect of $B A L$ and $B A L$ glucoside therapy in dogs initiated 2 hours after the oral administration of $30 \mathrm{mgm}$. per kgm. of $\mathrm{HgCl}_{2}\left(>L D_{100}\right)$

\begin{tabular}{|c|c|c|c|c|c|c|}
\hline \multirow{2}{*}{ Dog no. } & \multirow{2}{*}{$\begin{array}{l}\text { Time of } \\
\text { death }\end{array}$} & \multicolumn{5}{|c|}{ Serum urea nitrogen (mgm. per $100 \mathrm{ml}$. serum) } \\
\hline & & $\begin{array}{c}\text { Before } \\
\mathrm{HgCl}_{2}\end{array}$ & $48 \mathrm{hrs}$. & 96 hrs. & $120 \mathrm{hrs}$. & $\begin{array}{c}2 \text { to } \\
2 \frac{1}{2} \text { wks. }\end{array}$ \\
\hline \multicolumn{7}{|c|}{ After $B A L$ therapy } \\
\hline $\begin{array}{l}45 \\
46 \\
47\end{array}$ & $\begin{array}{l}\mathrm{S}^{*} \\
17 \text { days } \\
\mathrm{S}\end{array}$ & $\begin{array}{r}10.5 \\
5.2 \\
8.6\end{array}$ & $\begin{array}{r}8.8 \\
5.6 \\
12.7\end{array}$ & $\begin{array}{r}11.9 \\
7.8 \\
19.8\end{array}$ & & $\begin{array}{r}9.0 \\
11.4\end{array}$ \\
\hline $\begin{array}{l}48 \\
49 \\
32\end{array}$ & $\begin{array}{l}\text { S } \\
144 \text { hrs. } \\
168 \text { hrs. }\end{array}$ & $\begin{array}{r}15.4 \\
9.4 \\
17.7\end{array}$ & $\begin{array}{l}16.7 \\
15.4 \\
10.4\end{array}$ & $\begin{array}{r}23.0 \\
46.3 \\
9.3\end{array}$ & & 16.1 \\
\hline $\begin{array}{l}33 \\
34 \\
35 \\
58\end{array}$ & $\begin{array}{c}\text { S } \\
144 \text { hrs. } \\
\text { S } \\
\text { S }\end{array}$ & $\begin{array}{r}17.8 \\
8.9 \\
19.5 \\
9.8\end{array}$ & $\begin{array}{r}15.2 \\
9.6 \\
19.9 \\
11.2\end{array}$ & $\begin{array}{l}12.7 \\
11.8 \\
23.0 \\
14.5\end{array}$ & & $\begin{array}{l}11.4 \\
21.2\end{array}$ \\
\hline \multicolumn{7}{|c|}{ After $B A L$ glucoside therapy } \\
\hline $\begin{array}{l}108 \\
109 \\
110\end{array}$ & $\begin{array}{l}S \\
S \\
S\end{array}$ & $\begin{array}{l}9.0 \\
7.9 \\
6.3\end{array}$ & $\begin{array}{l}7.0 \\
7.8 \\
5.1\end{array}$ & & $\begin{array}{r}20.7 \\
6.2 \\
4.9\end{array}$ & $\begin{array}{l}6.1 \\
5.5 \\
4.6\end{array}$ \\
\hline $\begin{array}{l}111 \\
112 \\
113\end{array}$ & $\begin{array}{c}120 \mathrm{~S} \\
\mathrm{~S}\end{array}$ & $\begin{array}{r}9.3 \\
9.7 \\
10.6\end{array}$ & $\begin{array}{r}9.3 \\
15.5 \\
10.7\end{array}$ & & $\begin{array}{r}32.4 \\
9.5\end{array}$ & $\begin{array}{r}12.7 \\
9.5\end{array}$ \\
\hline $\begin{array}{l}114 \\
115\end{array}$ & $\begin{array}{l}\text { S } \\
\text { S }\end{array}$ & $\begin{array}{r}7.7 \\
13.7\end{array}$ & $\begin{array}{r}5.4 \\
15.5\end{array}$ & & $\begin{array}{r}5.9 \\
11.8\end{array}$ & $\begin{array}{r}9.6 \\
13.8\end{array}$ \\
\hline
\end{tabular}

${ }^{*} \mathrm{~S}=$ Survival.

dog showed a progressive rise in serum urea $\mathrm{N}$. In none of the 5 remaining dogs which succumbed could death be attributed to the toxic actions of mercury on the kidney.

Of the 5 animals treated with BAL 5 hours after the administration of $\mathrm{HgCl}_{2}, 3$ survived. The 2 deaths occurred on the third and fourth days in animals with 48-hour serum urea $\mathrm{N}$ levels of 57 and $52 \mathrm{mgm}$. per cent, respectively. BAL glucoside was also highly effective when given 5 hours after oral poisoning with mercury. Two of 6 animals succumbed, 1 within 24 hours and the other within 48 hours; both exhibited a severe hemorrhagic enteritis. Of the 4 surviving animals, none showed evidence of systemic mercury poisoning.

\section{DISCUSSION}

It is evident from the above data that the 3 mercaptans investigated were able to protect 
against the systemic effects of mercury, even when treatment was delayed. In view of the ability of these compounds to form mercaptides in vitro, it must be assumed that similar reactions occur in vivo. Moreover, the fact that early treatment with mercaptans affords complete protection, indicates that the mercaptides formed in vivo are sufficiently non-dissociated to prevent combination of $\mathrm{Hg}^{++}$with essential cellular enzymes. Lastly, the observation that the dithiols are therapeutically effective when administered 2 to 3 hours after intravenous mercury in dogs, indicates that the dithiols can remove mercury already combined intracellularly.

Of the 3 mercaptans studied, the order of decreasing efficacy was BAL glucoside, BAL, and thiosorbitol. Thiosorbitol possesses certain pharmaceutical advantages over BAL in that it is a crystalline, water-soluble compound which may be readily administered by intravenous injection. Although it is much less toxic than BAL in mice and rabbits, the greater efficacy of BAL at dose levels which are well within the range of human tolerance (3) favors the choice of the dithiol for clinical use. The fact that the monothiols were less effective than the dithiols in reversing arsenic linkage with proteins has been demonstrated by British investigators (2). By analogy, monothiols might be expected to be less effective in the treatment of mercury poisoning. The in vitro observations reported above indicated a greater dissociation of $\mathrm{Hg}$ (thiosorbitol) $)_{2}$ than of either $\mathrm{Hg}$ -

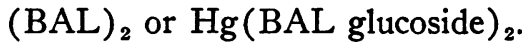

In dogs there was definite evidence that $\mathrm{BAL}$ glucoside was more effective than BAL in the treatment of both oral and intravenous mercury poisoning. This fact is chiefly of academic interest at the present time, inasmuch as BAL glucoside is not available in a sufficiently pure form to warrant clinical trial. However, it is not unlikely that compounds superior to BAL in protecting against the toxic effects of heavy metals would result from further investigations on dithiols.

Sufficient data are not available to account for the greater efficiency of the glucoside. However, certain conclusions may be drawn tentatively from observations on the toxicities of the preformed complexes. $\mathrm{Hg}(\mathrm{BAL})_{2}$ was no less toxic than $\mathrm{HgCl}_{2}$ on a molar basis. On the other hand, $\mathrm{Hg}$ -
BAL glucoside was definitely less toxic than inorganic mercury. Inasmuch as the available data indicate that $\mathrm{Hg}-\mathrm{BAL}$ glucoside dissociates to a greater extent than does $\mathrm{Hg}(\mathrm{BAL})_{2}$, one cannot relate the observed differences in toxicity to dissociability.

It is known that BAL is readily oxidized in the body. Therefore, the undiminished toxicity of BAL complexes could be explained by the intracellular oxidation of the complexes with the release of cationic mercury. In the treatment of mercury poisoning, a sustained concentration of BAL is maintained by repeated injections. Thus, a recombination of $\mathrm{Hg}^{++}$released by oxidation with available BAL is possible. During the time that BAL is available, renal excretion of the complex can be effected. The fact that BAL promotes the excretion of arsenic $(2,3)$ and cadmium (6) has already been reported. Data on the effects of mercaptans on the excretion of other heavy metals are not yet available.

Danielli and coworkers (1) have suggested that BAL glucoside remains extracellular in its distribution. An extracellular volume distribution of the $\mathrm{Hg}-\mathrm{BAL}$ glucoside complexes would explain their decreased toxicities. In keeping with this explanation, $\mathrm{Hg}$ (BAL glucoside) ${ }_{2}$, a compound of higher molecular weight than $\mathrm{Hg}-\mathrm{BAL}$ glucoside, might be expected to penetrate cells more slowly and thus be less toxic. However, it must also be assumed that the difference in the degree of dissociation of the 2 complexes may play some rôle in their relative toxicities.

An extracellular distribution of a mercaptan would not preclude the possibility of the mercaptan's removing heavy metals from intracellular enzymes. A significant degree of dissociation of the metallo-enzyme complex would result in an appreciable concentration of diffusible cationic metal which would be available for combination with the mercaptan at an extracellular site to form a mercaptide of lower dissociability. Thus, a continuous removal of metal from the cell could be accomplished.

The fact that BAL, at dose levels within the range of human tolerance, is highly effective in preventing systemic effects of mercury following oral mercury poisoning in dogs provides the experimental background for the clinical use of BAL in mercury poisoning in humans. In the above 
study, none of the dogs received the adjuvant and supportive therapy which would be afforded human patients. Thus in the majority of animals, the metabolic disturbances resulting from the severe diarrhea, which was invariably present before delayed treatment was initiated, could only. be corrected by voluntary ingestion of food and water, and adequate renal function. The fact that treatment was so efficacious that a majority of dogs survived even when therapy was delayed for 5 hours, attests to the value of BAL in the treatment of mercury poisoning more convincingly than if 100 per cent survived with the aid of intensive local and supportive therapy. In support of this statement is the fact that in only 1 instance did an orally poisoned, BAL-treated dog die in uremia.

\section{SUMMARY AND CONCLUSIONS}

1. Three mercaptans, BAL, BAL glucoside and 1-thiosorbitol, have been employed in the treatment of acute intravenous $\mathrm{HgCl}_{2}$ poisoning in the rabbit. $\mathrm{BAL}$ and $\mathrm{BAL}$ glucoside have been employed in the treatment of acute intravenous and oral $\mathrm{HgCl}_{2}$ poisoning in the dog.

2. Rabbits receiving $3.0 \mathrm{mgm}$. per $\mathrm{kgm}$. of $\mathrm{HgCl}_{2}\left(\mathrm{LD}_{96}\right)$ intravenously, were completely protected by 3 doses of $0.1 \mathrm{mM}$. per $\mathrm{kgm}$. of any of the mercaptans, provided therapy was initiated within 5 minutes. Therapy was progressively less effective with decreasing dosage or increasing delay before initiation. The order of decreasing efficacy of the 3 mercaptans was BAL glucoside, BAL and 1-thiosorbitol.

3. Dogs receiving $4.0 \mathrm{mgm}$. per $\mathrm{kgm}$. of $\mathrm{HgCl}_{2}$ intravenously $\left(L D_{100}\right)$, were completely protected from the renal effects of the metal by 3 equal doses of BAL totaling $0.15 \mathrm{mM}$. per $\mathrm{kgm}$. when treatment was delayed for 30 minutes. Striking protection was still afforded both by BAL glucoside and by BAL when treatment was delayed for 2 hours.

4. Of 44 dogs receiving $30 \mathrm{mgm}$. per $\mathrm{kgm}$. of $\mathrm{HgCl}_{2}$ orally $\left(\mathrm{LD}_{100}\right)$ in which treatment with a total of $0.15 \mathrm{mM}$. per $\mathrm{kgm}$. of BAL or BAL glucoside was delayed for from 2 to 5 hours, 28 survived and only 1 animal died in uremia. No local therapy was employed, and the deaths which occurred could be attributed to gastro-enteritis and inanition.

5. The reactions between mercaptans and mercury in vitro have been studied, and tentative formulae for the mercaptides formed have been presented. The toxicities of the preformed mercaptides have been determined, and the mechanism of action of mercaptans in detoxifying mercury discussed in the light of these data.

\section{BIBLIOGRAPHY}

1. Danielli, J. F., Danielli, M., Mitchell, P. D., Owen, L. N., and Shaw, G., Personal communication, 1944.

2. Peters, R. A., Stocken, L. A., and Thompson, R. H. S., British Anti-Lewisite (BAL). Nature, 1945, 156, 616.

3. Waters, L. L., and Stock, C. C., BAL (British Anti(Lewisite). Science, 1945, 102, 601.

4. Rosenthal, S. M., Experimental studies on acute mercurial poisoning. Pub. Health Rep., 1933, 48, 1543.

5. Modell, W., Chenoweth, M. B., and Krop, S., Toxicity of BAL in cats. To be published.

6. Tepperman, H. M., and Gilman, A., Unpublished, 1945. 